\title{
Informatization Teaching Practice of Landscape Design Courses
}

\author{
Hui Xiong \\ Hunan Agricultural University \\ Hunan, China \\ Email: 30124755@qq.com
}

\begin{abstract}
The integration of information technology and curriculum teaching is an important way for school education informatization work, and it is also a key measure to improve teaching quality. Landscape Design curriculum teaching is facing the problems of abstract design thinking, lack of communication, and quick resource renewal. By the support of information technology, the creation of mobile classrooms and the sharing of information platforms, it is possible to solve difficult problems in curriculum teaching. From the instructional design, teaching methods, and teaching outlines, the teaching practice of information reform in the Landscape Design course carried out at Hunan Agricultural University is introduced. Through the use of professional technology software and mobile classroom information methods to solve teaching problems, it proposes that the information technology teaching reform proposal includes that teaching design is the top, multimedia courseware is the foundation, cultivating ability is the goal, adapting to the times is an initiative, and education enthusiasm is the driving force.
\end{abstract}

Keywords: Instructional Design; Mobile Classroom; Teaching Thinking

\section{INTRODUCTION}

The 10-year development plan for education informatization (2011-2020) pointed out that the integration of information technology and higher education should be promoted, innovative personnel training models should be innovated, and the overall improvement of education quality should be promoted ${ }^{[1]}$. From the long-term strategic goals to the recent education program in China, the integration of information and curriculum teaching has very important practical significance for implementing national policies, improving teaching effectiveness, and cultivating innovative talents.

In recent years, Landscape Design course group of Horticulture \& Landscape School at Hunan Agricultural University has actively explored new teaching methods in the context of informatization. And the Landscape Architecture Design courses and Landscape Design courses have won the first prize of the 2015 and 2017 Hunan Informatization Awards for their excellent ppt design and mobile classroom application. In the teaching practice, the course group constantly tries to use information technology to achieve better teaching results.
The landscape design course is a professional core course for landscape architecture and gardening major. Students' mastery of the course directly affects the students' understanding and use of the major. The course requires students to understand the entire process of landscape design, master basic design theories and cutting-edge ideas, and have the ability to work independently or to complete the design of different-scale site designs in teams. Due to the requirement of high practical ability, abstract design thinking, and quick case updates in the course, it is necessary to solve the difficulties of design thinking demonstration in the traditional teaching process, the difficulties of instant communication in the learning process, the rapid and massive update of resources, and so on.

\section{NECESSITY AND FEASIBILITY OF INFORMATIONIZED CLASSROOM TEACHING REFORM}

For the above-mentioned problems in landscape design teaching, this paper is to analyze that: First, teachers need to have a good way for students to easily understand difficult knowledge points, that is, they use logical induction and virtual construction to demonstrate the abstract design process and use contextualized information display technology to reproduce the design process and composition of the art in the mind, and regard technology as a tool to support the internalization of knowledge to strengthen the understanding of abstract thinking; Second, an environment of self-learning and self-thinking should be created for students. Mobile phones are the most frequently used facilities in today's society. Through the mobile classroom APP, traditional learning methods will be changed and learning can be conducted anywhere and anytime; Thirdly, to build a database of system resources supporting knowledge, where teachers and students act as resource acquirers and resource builders at the same time, which helps to provide teachers and students with convenience. In the information technology environment, intelligent classrooms have the multiple characteristics of personality collaboration, intelligent tracking, tool enrichment, and activity intelligence ${ }^{[2]}$, which is exactly the solution to the problem of landscape design teaching.

\section{INFORMATIZATION TEACHING PRACTICE OF LANDSCAPE DESIGN COURSES}

Information-based teaching design is the key to the realization of information-based teaching. The landscape 
design courses of Hunan Agricultural University are for third-year undergraduates. Since 2015, the landscape design courses have been attempted informatization teaching reform, which will extend the time span from the original 1 semester to the current 2 semesters. The theoretical course hours are divided into 50 hours in the original 1 semester to 24 hours in the current two semesters. Using instructional design and teaching methods, and taking a specific knowledge point after the reform as an example, this paper has discussed the construction and practice of informationized teaching.

\section{A. Teaching Design}

At the beginning of the reform, the courses content was systematically sorted out and the chapter content and teaching objectives were reset. (As shown in Table 1)

TABLE 1 COMPARISON OF OLD AND NEW TEACHING DESIGN

\begin{tabular}{|c|c|c|c|c|c|c|}
\hline \multirow{2}{*}{ No. } & \multicolumn{3}{|c|}{ Original Teaching Design } & \multicolumn{3}{|c|}{ Improved Teaching Design } \\
\hline & Hours & Chapter Content & Teaching Goals & Hours & $\begin{array}{l}\text { Chapter } \\
\text { Content }\end{array}$ & Teaching Goals \\
\hline 01 & 6 & $\begin{array}{l}\text { Landscape Design } \\
\text { Basic Method }\end{array}$ & $\begin{array}{l}\text { To learn about the general } \\
\text { procedures of landscap design and } \\
\text { to master the contents and methods } \\
\text { of the basic survey. }\end{array}$ & 2 & Introduction & $\begin{array}{l}\text { To understand the concept of landscape } \\
\text { architecture, to establish a systematic } \\
\text { concept of landscape architecture; to } \\
\text { understand the entire process of landscape } \\
\text { design, and to cultivate a strong interest in } \\
\text { learning. }\end{array}$ \\
\hline 02 & 4 & Garden Design & $\begin{array}{l}\text { To understand the history, current } \\
\text { status and development trend of } \\
\text { the courtyard landscape, and to } \\
\text { master the design principles and } \\
\text { techniques of the garden green } \\
\text { space. }\end{array}$ & 6 & Site Reading & $\begin{array}{l}\text { To master the site survey method, develop } \\
\text { the habit of reading on the site, and to } \\
\text { establish a thinking pattern based on the } \\
\text { basic starting point of the user's appeal. }\end{array}$ \\
\hline 03 & 12 & $\begin{array}{l}\text { Residential Area } \\
\text { Landscape Design }\end{array}$ & $\begin{array}{l}\text { To understand the type and } \\
\text { characteristics of green space in } \\
\text { residential areas, to familiarize } \\
\text { with design specifications, and to } \\
\text { master the design methods of } \\
\text { green spaces in residential areas. }\end{array}$ & 8 & $\begin{array}{l}\text { Concept } \\
\text { Design }\end{array}$ & $\begin{array}{l}\text { To analyze the current situation of the site } \\
\text { and refine the concept of the site; to } \\
\text { master the concept of the design method, } \\
\text { and to reasonably choose the spatial layout } \\
\text { form according to the characteristics of the } \\
\text { site. }\end{array}$ \\
\hline 04 & 8 & $\begin{array}{lr}\text { Landscape } & \text { Design } \\
\text { of Roads } & \text { and } \\
\text { Squares } & \end{array}$ & $\begin{array}{l}\text { To understand the relevant } \\
\text { specifications of the road square, } \\
\text { to familiar with the basic types and } \\
\text { characteristics, and to master the } \\
\text { design principles and methods. }\end{array}$ & 8 & $\begin{array}{l}\text { Overall } \\
\text { Design }\end{array}$ & $\begin{array}{l}\text { To understand the overall design is the } \\
\text { systematic layout of multiple elements } \\
\text { such as roads, terrain, buildings, and } \\
\text { plants; And Can complete the overall } \\
\text { design of small and medium-sized sites } \\
\text { according to design intent. }\end{array}$ \\
\hline & 20 & $\begin{array}{l}\text { Comprehensive } \\
\text { Park Design }\end{array}$ & $\begin{array}{l}\text { To understand the concept, } \\
\text { development, function and type of } \\
\text { park, to familiarize with the } \\
\text { norms, and to master the principles } \\
\text { and methods of park design. }\end{array}$ & 24 & $\begin{array}{l}\text { Detailed } \\
\text { Design }\end{array}$ & $\begin{array}{l}\text { To understand the development history of } \\
\text { residences, road squares, and park } \\
\text { landscapes, to master the design points of } \\
\text { different types of landscapes, and to be } \\
\text { able to complete different types of } \\
\text { landscape designs independently or in } \\
\text { teams in light of actual conditions. }\end{array}$ \\
\hline
\end{tabular}

\section{B. Teaching Methods}

Use ARCS model in course teaching:

Attention: At the beginning of each session, arrange teaching sessions for videos, pictures, suspense, etc., and ask students questions to stimulate students' interest in inquiry;

b) Relevance: Provide corresponding case analysis for theoretical knowledge points.

Selecting cases allows students to make full use of existing knowledge to think about new knowledge and enable them to use new knowledge to solve real problems in the familiar environment. Link the teaching motivation with the students' various learning needs;

c) Confidence: Consider the advanced nature of learning in the setting of the course objectives and assignments, and let students know how to start, build confidence, and complete the design from the element to the whole process. Combine job topics with actual business projects. After parts of the students' works are revised and improved, they are used for project practice to inspire students' self-confidence;

d) Satisfaction: Students' design achievements are shared through the platform, and the teacher-student interaction becomes the interaction between students, allowing students to feel the learning gain and satisfaction.

Through the above four steps, students' learning motivation is triggered and students' interest in learning is stimulated.

\section{Teaching Outline}

Take the Park Landscape Design Course in Detailed Design (Chapter IV, Section III) as an example, and use the knowledge points of park types and design methods in 
the course to present the teaching outline, as shown in Table 2:

TABLE 2 TEACHING OUTLINE OF KNOWLEDGE POINTS IN PARK DESIGN

\begin{tabular}{|c|c|c|c|}
\hline Teaching process & Knowledge points & $\begin{array}{c}\text { Activity } \\
\text { arrangements }\end{array}$ & Teaching strategies \\
\hline $\begin{array}{l}\text { Pre-class micro } \\
\text { lessons }\end{array}$ & Park classification & Videos & Self-preparation of theoretical knowledge \\
\hline $\begin{array}{l}\text { Knowledge } \\
\text { Import/Knowledge } \\
\text { Discussion } \\
\text { (45min) }\end{array}$ & $\begin{array}{l}\text { Different types of park } \\
\text { features }\end{array}$ & $\begin{array}{l}\text { Image Analysis / } \\
\text { Class Discussion / } \\
\text { Mobile Classroom }\end{array}$ & $\begin{array}{l}\text { Voting mobile phone voting /Check the effect of } \\
\text { pre-class preview/Grouping Autonomous } \\
\text { Discussion of Park Characteristics /Submit the } \\
\text { group's summary. }\end{array}$ \\
\hline $\begin{array}{l}\text { Theoretical } \\
\text { exploration / Case } \\
\text { highlights } \\
(35 \mathrm{~min})\end{array}$ & Park design steps & $\begin{array}{l}\text { Example analysis/ } \\
\text { Video demonstration }\end{array}$ & $\begin{array}{l}\text { Use a step-by-step approach to analyze design } \\
\text { ideas, and present the composition of each design } \\
\text { stage with a video presentation. }\end{array}$ \\
\hline $\begin{array}{l}\text { Classroom practice } \\
(8 \mathrm{~min})\end{array}$ & $\begin{array}{l}\text { Campus Public Green } \\
\text { Zoning }\end{array}$ & Classroom exercises & $\begin{array}{l}\text { Familiarize with the site to carry out class } \\
\text { exercises to enhance students' hands-on interest. }\end{array}$ \\
\hline $\begin{array}{l}\text { Summary discussion } \\
(2 \mathrm{~min})\end{array}$ & & Mind mapping & $\begin{array}{l}\text { Review the course content of this section to } \\
\text { summarize development characteristics and } \\
\text { develop students' ability to summarize. }\end{array}$ \\
\hline Homework & $\begin{array}{l}\text { Complete classroom } \\
\text { practice site design }\end{array}$ & $\begin{array}{l}\text { Mobile Classroom/ } \\
\text { Student assessment }\end{array}$ & $\begin{array}{l}\text { Practice considering the relevance of the } \\
\text { classroom; Mobile phone platform presentation } \\
\text { and reviews to promote professional exchanges. }\end{array}$ \\
\hline $\begin{array}{l}\text { Teaching Reflections } \\
\text { (Teachers) }\end{array}$ & & Mobile Classroom & $\begin{array}{l}\text { Build related case libraries / check student } \\
\text { resource learning / publish course discussions and } \\
\text { opinions. }\end{array}$ \\
\hline
\end{tabular}

\section{V.CONCLUSION}

\section{A. Teaching Design is the Top}

The incorporation of information technology requires a reexamination of the teaching process and the reconstruction of instructional design. That is, in instructional design, teachers should have a meticulous plan from the analysis of factors, preparation of content, selection methods, to organization implementation, results evaluation, and reflection improvement.

\section{B. Multimedia Courseware is Foundation}

Course courseware is the cornerstone of information-based teaching. Grasping the structure of the entire curriculum is the key to building PPT. Completing a complete set of high-quality PPT construction not only has requirements for teachers in information technology, but also requires teachers to systematically and globally organize the entire teaching content, and complete the systematic construction of multimedia according to instructional design.

\section{Cultivating Ability is the Goal}

Mastering the ability to learn and nurturing lifelong learning habits are the inherent motivations that constantly encourage advancement. In the process of teaching courses, teachers should guide students to develop their own active learning abilities and habits.

\section{Adapting to the Times is an Initiative}

China is in an age of rapid information development. College students are often pioneers in the era. They are passionate about new media technologies and pursue individualized learning methods. Micro-courses can have a great deal of freedom of learning time and freedom of choice of knowledge points. Moreover, the micro-courses can be continuously updated to adapt to the development of information technology in the era to encourage teachers to continue to reform.

\section{E. Education Enthusiasm is the Driving Force.}

Every teaching reform requires a great deal of time and effort as well as needs to learn some new knowledge and thinking. If teachers don't have a passion for education and selfless love for students, teaching reforms cannot be achieved. Similarly, the devotion of teachers' feelings will arouse the resonance of students and promote the achievement of emotional goals in teaching, resulting in deeper impact on teaching and learning.

\section{REFERENCES}

[1] Ministry of Education of the People's Republic of China (2012).Ten Year Development Plan for Education Informationization (2011-2020).

[2] Tang Yewei, Pang Jingwen, Zhong Shaochun, \& Wang wei.(2014). Under the Information Technology Environment Wisdom Classroom Building Method and Case Study. China Educational Technology. 